\title{
Empowerment of Cadres in Early Detection of Danger Signs of Third Stage in Pregnancy
}

\author{
Elis Rosliantia), Yanti Srinayanti , and Rosmiati \\ STIKes Muhammadiyah Ciamis, Ciamis, Indonesia \\ a)Corresponding author: elisroslianti@gmail.com
}

\begin{abstract}
In general, family planning can be defined as an effort to regulate the number of pregnancies in such a way that it will have a positive impact on the mother, baby, father and family concerned and will not cause harm as a direct result of the pregnancy. Family planning is an attempt to regulate the population or the use of methods to regulate fertilization to help a person or family achieve certain goals. The purpose referred to here is an intentional arrangement of pregnancy by the family, which is not against the applicable laws or regulations and also the morals of Pancasila and for the welfare of the family. Giving understanding to couples of childbearing age that there are various kinds of contraceptives and their benefits, so that people can choose any contraceptive that suits the individual. With more benefits than side effects, especially to keep the pregnancy distance, and a prosperous family can be achieved. It is hoped that with careful family planning, pregnancy is something that is really expected so that it will avoid the act of terminating a pregnancy with abortion. Ciamis Regency is in the province of West Java, where the area is directly adjacent to two regencies, namely Banjar and Tasikmalaya. Its location in the center of the city makes the Benteng village not like a village in general.
\end{abstract}

Keywords : contraception, empowerment, equipment

\section{INTRODUCTION}

Pregnancy is a phase in a woman's life during the reproductive period, this includes a physiological process. Every pregnant woman wants safety during the process of pregnancy, childbirth until the puerperium (Lismayanti et al., 2021). Throughout this process, mothers need to adapt to various changes, both physical and psychological. Some pregnant women go through the process of pregnancy smoothly. However, there are some who experience problems during pregnancy, this situation is not the same for every pregnant woman (Ernawati, 2019).

Maternal mortality (MMR) is mostly caused by emergency complications during pregnancy. Complications that became the cause of death in Indonesia in 2015 were around 305 per 100,000 live births. Efforts to reduce MMR can be carried out with preventive and promotive efforts by consistently involving all elements in society (Lestari et al., 2016).

Early detection of symptoms and danger signs of pregnancy is the best effort to prevent serious disturbances to pregnancy or the safety of pregnant women. Predisposing factors and disturbances during pregnancy should be known early on so that maximum efforts can be made to prevent serious disturbances to both pregnancy and the safety of the mother and the baby she is carrying. Danger signs of third trimester pregnancy include vaginal bleeding, severe headache, blurred vision, swelling of the face or hands, less fetal movement than usual, premature rupture of membranes, preeclampsia and eclampsia (Rohmatika \& Mar, 2020)

The problem of maternal mortality can be caused by non-technical factors such as powerlessness, low education levels and the low status of women (Firmansyah et al., 2021). Other factors that affect women's health are poverty, limited access to quality health services and low research on women's health. Cultural factors in the community also influence, such 
as those who still carry out cultural practices that are harmful to pregnancy (Juita, Laila, \& Hevrialni, 2017).

Efforts to overcome these problems need to involve various other related sectors that can be involved to overcome or deal with health problems related to pregnancy, which are high risk, one of which is through the empowerment of health cadres. This empowerment effort is realized by increasing the role and involvement of health workers and the community (Aprilita Br Sitepu, 2021).

Early detection by health workers and the community about the presence of risk factors and complications, as well as adequate treatment as early as possible, is the key to success in reducing MMR and IMR. (Ariyanto, Setiawan, \& Oktavia, 2021). Danger signs of pregnancy are signs that indicate there is a danger that can occur during pregnancy which if not reported or detected can cause maternal death. Danger signs of pregnancy must be handled and detected early on properly because any danger signs of pregnancy, childbirth and postpartum can lead to further complications (Desmarnita \& Mulyanti, 2019).

Family is the smallest unit in society, it should be able to recognize the health condition of family members who are experiencing pregnancy. Families need to have adequate knowledge about the danger signs of pregnancy so that they can identify the danger signs and anticipate them early (Firmansyah, Setiawan, \& Ariyanto, 2021). The better the knowledge of pregnant women about the danger signs of pregnancy, the more willing the mother will be to have her pregnancy checked regularly to health workers during her pregnancy period. High knowledge supports proper behavior in pregnancy care (Hutasoit et al., 2021).

Prenatal care or Ante Natal Care (ANC) is important to monitor the health of the mother and fetus. The number of ANC affects the mother's knowledge about the danger signs during pregnancy. Mothers who perform ANC $\geq 4$ times have knowledge of danger signs during pregnancy 11 times better than mothers who only visit once (Ayu \& Dewi, 2017).

Apart from mothers, husbands as partners and companions have a very important role in protecting the health of mothers and their children. One of the duties of the husband as the head of the household is decision making. Good decisions are supported by knowledge of the problem (Setiawan, Roslianti, \& Firmansyah, 2020). One of the important knowledge possessed by husbands about maternal and neonatal health is knowing the danger signs during pregnancy in the hope of preventing delays in recognizing emergency danger signs and getting adequate health care (Palupi, Fakhidah, \& Utami, 2016).

Cintanagara Village is a village located in the Jatinagara District, Ciamis Regency, West Java Province. Most of which affect women's health is the case of pregnancy. The results of the preliminary study using a questionnaire obtained data that the cadres had not received training on early pregnancy detection. Health cadres hope to gain knowledge about the introduction of danger signs in pregnancy, in order to provide counseling to the public, especially families who have family members who are pregnant (Palupi et al., 2016).

One of the roles of health cadres in early detection of pregnancy is through the provision of health education regarding the introduction of danger signs in pregnancy so that the public gains insight and motivation to carry out further therapy or treatment (Setiawan, Firdaus, Ariyanto, \& Nantia, 2020). Efforts to increase the role and function of cadres need to get support in the form of debriefing health cadres, namely cadre training related to pregnancy (Solehati, Sari, Lukman, \& Kosasih, 2018).

\section{METHOD}

The Community Service Activities carried out are a collaboration between the Research and Community Service Institute (LPPM) STIKes Muhammadiyah Ciamis and the LazisMu Ciamis Humanitarian Institution which consists of 3 stages, namely planning, implementation and evaluation. Planning activities begin with a situation analysis based on the D-III Nursing 
Study Program roadmap of STIKes Muhammadiyah Ciamis regarding research and community service. After the formation of the committee and activity personnel, a preliminary study is carried out to determine the right time, place and topic according to the needs of the local community.

Intensive coordination was carried out with the Ciamis Regency government which was delegated to the Regional Technical Implementation Unit (UPTD) for the Jatinagara Subdistrict Health Center, religious leaders, community leaders and leaders at the RT/RW level, Lurah and Village Heads. This aims to ensure that the series of activities can be socialized to all levels of society who are participants in Community Service activities.

The implementation of activities is carried out through learning videos. The counseling participants were 32 people who were in the Posyandu Kenanga II area, Cintanagara Village. The implementers in this community service activity are lecturers and students of the D3 and S1 Nursing study programs.

Counseling is carried out by referring to the Extension Program Unit (SAP), which has been prepared, namely:

1. Opening

Saying greetings

2. Introduction

The moderator introduces himself and reads the curriculum vitae of the resource person

3. Pre-Implementation Evaluation

The evaluation in this section aims to explore participants' knowledge about the topics to be delivered including early detection of danger signs of third stage pregnancy. The method used is direct question and answer between the informants and participants at random. Initially, the resource person gave prepared questions and then gave an open opportunity to all participants to answer these questions. Next, the resource person appointed other participants at random to answer the questions.

4. Main Material

Submission of the main material is done by the lecture method. The resource person first conveys the objectives and criteria for the results of the activities held. Furthermore, the resource persons sequentially conveyed the material using instructional video media. The main points of the material conveyed were the early detection of danger signs of the third stage of pregnancy.

5. Discussion

After the main material is delivered, it opens the opportunity for all participants to ask questions about the material that still requires explanation. The discussion session was opened for two terms, and each term was given the opportunity for 4 participants.

6. Post-Implementation Evaluation

Post-Implementation Evaluation aims to explore participants' knowledge after the counseling is given. In the first term, the resource person randomly appointed three participants to answer the prepared questions. While in the second term, the resource person provided an open opportunity for all participants to answer questions.

7. Clossing

Delivering conclusions from the entire series of events and closing with prayers and closing greetings.

The last stage is evaluation. All teams involved in outreach activities conduct evaluations based on the indicators and outcome criteria listed in the SAP. The checklist or evaluation sheet is prepared by the observer to control the series of extension activities so that the evaluation notes can be discussed in the evaluation activities.

\section{RESULT AND DISCUSSION}

The implementation of health cadre education activities took place at the Posyandu Kenanga 2, Cintanagara Village, Jatinagara Health Center. The number of training participants was 32 
people, consisting of health cadres from the local area. Furthermore, the provision of training materials for health cadres on the introduction of danger signs in pregnancy. The training participants received a training learning video containing guidelines for health cadres aimed at making it easier for cadres to provide health education to families in their area who have pregnant women.

In addition to material in the form of theory, cadres participate in practical activities, namely how to use tools (instruments) to assess pregnancy. Furthermore, the cadres are encouraged to follow up on the discovery of danger signs in the case of pregnant women, to be referred according to the referral system material that has been submitted. During the question and answer activity, the cadre training participants seemed very enthusiastic about asking various questions about pregnancy.

The results of the evaluation show that the activities were carried out well in accordance with the indicators and results criteria in the Evaluation Sheet instrument. The evaluation sheet is based on five dimensions, namely Punctuality, Cadre Participation, Knowledge, Job Description and problem solving. The evaluation sheet was filled in by two independent observers.

Timeliness is one of the important dimensions in measuring the success of an activity. In fact, in some large and important activities, the timeline is the most standard main performance to measure the success of an activity.

Participation referred to in this activity is the involvement of the target or subject of physical and psychological activities in outreach activities (Haldane et al., 2019). The purpose of participation is the success or achievement of a community target and goal. Physically present in activities, psychologically providing good feedback on the entire series of activities. This shows that individuals understand the benefits that will be obtained from a community service. Therefore, the value of participation is measured based on the number and responses of participants during the activity (Aprina, 2017).

The number of participants who were invited to this activity were 32 people with the inclusion criteria of cadres in Cintanagara Village, married and willing to participate in the activity from beginning to end voluntarily. Feedback or participant response is measured by the involvement of participants in the pre-post implementation evaluation process and discussion sessions (Adella \& Purnamasari, 2021). The participant's response shows that there is motivation to benefit from the information conveyed (Yunita, Putri, \& Viridula, 2017).

In the discussion session, the two terms that were planned for four people turned out to be only filled by three questioners. This happened not because it did not meet the target, but because it was adjusted to the available time limit. Therefore, it is very important to pay attention to time considerations so that community service activities in the form of counseling or health education are further extended. The time plot and duration of the discussion session can be set at the time of SAP preparation so that the time set is effective and efficient. So that all participants who have the drive to be active in the discussion session can be accommodated (Pratiwi, 2021).

Knowledge is a series of study activities to find explanation, or a method for obtaining a rationalempirical understanding of knowledge in various aspects, including health. Health promotion with counseling is one of the activities that can be observed to become new knowledge or strengthen and clarify old knowledge. So, an important indicator that must be included in the evaluation sheet is the knowledge status of the participants (Hadijah \& Amin, 2021).

The results of the observations documented in the evaluation sheet showed an increase in participants' knowledge. Pre-Implementation Evaluation shows that one out of four people who provide feedback on the questions given, can answer the questions correctly. This shows the change in the status of knowledge, before and after the counseling was carried out.

Job description is an effort to control the role of everyone involved in an activity. The description of each person's duties and functions becomes more organized so that it supports the success of an event. This point is an indicator of the success of an event. However, all activities took place 
according to the target, so the job description indicators were considered adequate for the health promotion.

Problem solving in an activity, the potential and risk of problems cannot be avoided. However, careful preparation needs to be done to predict the various possibilities that occur so as to reduce the essence of an activity. These predictions are a solution that needs to be prepared. However, this activity can take place without essential obstacles.

\section{CONCLUSION}

In accordance with the evaluation results, health promotion activities with cadre empowerment counseling in early detection of danger signs of third stage pregnancy have been successful with indicators of Timeliness and Duration, Participation, Knowledge, Job Description and problem solving. This activity needs to be encouraged and collaborated with all related elements such as the Health Office, Puskesmas and local community leaders, so that public awareness continues to increase along with the increase in the level of knowledge.

\section{ACKNOWLEDGMENT}

The author would like to thank LPPM STIKes Muhammadiyah Ciamis which has funded.

\section{REFERENCES}

Adella, S., \& Purnamasari, A. (2021). Teknik Relaksasi untuk Menurunkan Kecemasan Pada Ibu Hamil di Wilayah Puskesmas Pakualaman. Psyche 165 Journal, 14(3), 303-309. https://doi.org/10.35134/jpsy165.v14i3.115

Aprilita Br Sitepu, T. S. (2021). Tingkat pengetahuan ibu hamil trimester 3 tentang Perdarahan persalinan kala iv di klinik romana tahun 2021. Jintan, 1(2), 58-67.

Aprina, N. A. (2017). Analisis faktor yang berhubungan dengan partisipasi suami dalam menjaga kesehatan kehamilan. Kesehatan, 8(1), 98-107.

Ariyanto, H., Setiawan, H., \& Oktavia, W. (2021). A Case Study: Murotal Distraction to Reduce Pain Level among Post-Mastectomy Patients. International Journal of Nursing and Health Services (IJNHS), 4(3), 325-331.

ayu indah rachmawati, ratna dewi puspitasari, eka cania. (2017). faktor-faktor yang mempengaruhi kunjungan antenatal care ANC ibu hamil, 7(November), 72-76.

Desmarnita, U., \& Mulyanti, Y. (2019). Pengaruh Promosi Kesehatan Melalui Buku Praktis Kesehatan Ibu Hamil Preeklamsia Terhadap Pengetahuan Kader Kesehatan. Jkep, 4(1), 44-53. https://doi.org/10.32668/jkep.v4i1.279

Ernawati, A. (2019). Masalah gizi pada ibu hamil nutritional issues among pregnant mothers. Litbang, XIII(1), 60-69.

Firmansyah, A., Setiawan, H., \& Ariyanto, H. (2021). Studi Kasus Implementasi Evidence-Based Nursing: Water Tepid Sponge Bath Untuk Menurunkan Demam Pasien Tifoid. Viva Medika: Jurnal Kesehatan, Kebidanan Dan Keperawatan, 14(2), 174-181.

Firmansyah, A., Setiawan, H., Wibowo, D. A., Rohita, T., \& Umami, A. (2021). Virtual Reality (VR) Media Distraction Relieve Anxiety Level of the Children During Circumcision. In 1st Paris Van Java International Seminar on Health, Economics, Social Science and Humanities (PVJ-ISHESSH 2020) (pp. 611-614). Atlantis Press.

Hadijah, S., \& Amin, W. (2021). Penyuluhan dengan media audiovisual memengaruhi tingkat pengetahuan ibu tentang kebutuhan dasar ibu hamil. Kebidanan Malakbi, 2(2), 46-51.

Haldane, V., Chuah, F. L. H., Srivastava, A., Singh, S. R., Koh, G. C. H., Seng, C. K., \& LegidoQuigley, H. (2019). Community participation in health services development, implementation, and evaluation: A systematic review of empowerment, health, community, and process outcomes. PloS One, 14(5), e0216112-e0216112. 
https://doi.org/10.1371/journal.pone.0216112

Hutasoit, E. S., Yanti, N., Hayati, S., Azwar, Y., \& Utami, K. (2021). Pemantauan Kecemasan dan Lama Persalinan Kala I pada Ibu Bersalin dengan Pelaksanaan Yoga Kehamilan. AbdimasHip, 2(2), 96-101.

Juita, Laila, A., \& Hevrialni, R. (2017). Pengaruh Senam Hamil dengan Lamanya Persalinan Kala I dan Kala II di Bidan Praktik Mandiri Dince Safrina Pekanbaru Tahun 2017. Jurnal Ibu Dan Anak, 5(1), 1-8.

Lestari, K. P., Sriningsih, I., Lestari, T. W., Parwati, D. M., Suheri, T., \& Hartati, L. E. (2016). Penyegaran kader tentang tanda - tanda Kehamilan, cara mengatasi masalah kehamilandan persiapan persalinan. Link, 12(1), 26-29.

Lismayanti, L., Ariyanto, H., Azmi, A., Nigusyanti, A. F., \& Andira, R. A. (2021). Murattal Al-Quran Therapy to Reduce Anxiety among Operating Patients. Genius Journal, 02(1), 9-15.

Palupi, F. H., Fakhidah, L. N., \& Utami, U. (2016). Tingkat pengetahuan kader kesehatan tentang tanda bahaya kehamilan di desa bolon kecamatan colomadu. Maternal, 7(167), 47-58.

Pratiwi, R. D. et al. (2021). Education on the importance of nutrition for pregnant women. Jurnal Abdi Masyarakat, 2(1), 101-105.

Rohmatika, D., \& Mar, M. (2020). Pemberdayaan Masyarakat Kader Dalam Upaya Pencegahan Dan Penanganan Anemia Pada Ibu Hamil. Pengmas Al-Irsyad, 3(1), 65-73.

Setiawan, H., Firdaus, F. A., Ariyanto, H., \& Nantia, R. (2020). Pendidikan Kesehatan Perilaku Hidup Bersih dan Sehat di Pondok Pesantren, 1(3), 118-125.

Setiawan, H., Roslianti, E., \& Firmansyah, A. (2020). Theory Development of Genetic Counseling among Patient with Genetic Diseases. International Journal of Nursing Science and Health Services, 3(6), 709-715. https://doi.org/http://doi.org.10.35654/ijnhs.v3i6.350 Abstract.

Solehati, T., Sari, C. W. M., Lukman, M., \& Kosasih, C. E. (2018). Pengaruh Pendidikan Kesehatan Terhadap Pengetahuan Deteksi Dini Dan Pencegahan Anemia Dalam Upaya Menurunkan Aki Pada Kader Posyandu. Jurnal Keperawatan Komprehensif (Comprehensive Nursing Journal), 4(1), 7-12. https://doi.org/10.33755/jkk.v4i1.75

Yunita, A., Putri, S. I., \& Viridula, E. Y. (2017). Systematic review: deteksi dini pencegahan preeklamsia pada ibu hamil. Medika, 6(1), 1-15. 